\title{
Operation of a cheap underwater house
}

\author{
John R. Heath \\ The Marine Station, Millport, Scotland \\ and \\ Department of Applied Microbiology and Biology, University of Stratbclyde, Scotland
}

\begin{abstract}
KURZFASSUNG: Der Betrieb eines billigen Unterwasserhauses. Unterwasserhäuser wurden während der letzten Jahre angewendet, um lange Arbeitszeiten im Tiefwasser zu ermöglichen. Sie erwiesen sich aber als sehr kostspielig. Vor kurzem hat eine Gruppe Amateurtaucher ein Unterwasserhaus gebaut und geprüft, um zu beweisen, daß ein längerer Aufenthalt unter Wasser möglich und zudem nicht kostspielig ist. Das Haus („GLAUCUS“), ein zylindrischer Stahlbau von 3,5 m Länge und $2 \mathrm{~m}$ Durchmesser, blieb während einer Woche mit zwei Mann Besatzung in einer Wassertiefe von $10,7 \mathrm{~m}$ (35 Fuß). Es hatte eine Lukenöffnung an der Unterseite und konnte zum Ablassen oder zur Dekompression nicht abgedichtet werden. Elektrischer Strom wurde durch einen Stromerzeuger an Land geliefert, den eine Oberflächenmannschaft betreute, die auch Mahlzeiten zubereitete und ins Haus brachte. Das Haus besaß ein selbständiges Lüftungskontrollsystem mit einer Mischung von 15 bis $18 \% \mathrm{O}_{2}$ in $\mathrm{N}_{2}$. Sehr starke Winde hatten die Sicht unter Wasser verringert und die Arbeit erschwert, das Leben im Haus jedoch nicht beeinträchtigt. Am Ende der Woche wurde die Dekompression durch eine Erhöhung des Sauerstoffanteils der Luft vorgenommen. Beim Aufheben des Hauses gab es einige Schwierigkeiten, daher schwamm die Mannschaft nach oben und ließ das Haus für späteres Emporheben zurück. Es wird die Ansicht geäußert, daß die weitere Entwicklung billiger und einfacher Unterwasserhäuser für manche Arbeitsgebiete unter Wasser von großem Wert sein könnte.
\end{abstract}

\section{INT'RODUCTION}

Diving techniques are now widely accepted as a useful research tool. This is largely due to the development of simple and reliable free diving techniques, though it should not be forgotten that much work has been done using older methods.

The standard diving dress of the type invented by SIEBE in 1837 has been used for biological work, for example by Milne-Edwards (De Quatrefages 1857), who used an apparatus of similar design in Sicily, mainly for collection of material for laboratory studies. The revolutionary airline/demand valve apparatus of RoUQUAYroL and Denayrouze (see Dugan 1960 for a short description) seems, however, to have been largely neglected by biologists, and most early workers used the simple diving helmet which is still in use at the present day. KITcHING, working on the ecology of the shallow sublittoral in rocky areas (Kitching, Macan \& Gilson 1934, Kitching 1941), mentions the main disadvantages of this method. These are cold, which severely limits the time spent underwater, and the use of a pump which requires an operator, 
and the efficiency of which limits the working depth. In certain circumstances the need for an airline to the surface can also be a hindrance.

The ready availability of a self-contained open-circuit apparatus in the 1950's and its use for pleasure diving resulted in a great increase in biological research using diving methods. As was earlier pointed out (Kitching, Macan \& Gilson 1934, Drach 1952), this allowed investigations into the ecology of the rocky sublittoral, an area notoriously difficult to study by other methods, and much work has been done in this field in many areas. Diving methods have also been brought to bear on other problems, however, such as behaviour, particularly that of fish, and the ecology of caves.

Much of this work has involved a large amount of diving - that of Hiat \& Strasburg (1960), Laborel \& Vacelet $(1958,1961)$ and Gosline (1965), for instance. Long periods of diving pose serious problems, one of them, as KITCHING noted, being cold. Although good protective clothing is available, this is often only effective in shallow water, since pressure reduces the thickness of insulating gas layers, and the conductivity of the gas is increased with its increasing density. The reduction in insulation is quite noticeable in wet suits below about $12 \mathrm{~m}$. Most protective clothing also makes the diver clumsy, but one civil engineering company uses traditional helmet diving suits for long jobs largely because of their greater warmth, and in spite of their added cost and inconvenience, while most amateur divers in Britain prefer the clumsier $1 / 4^{\prime \prime}$ neoprene wet suits to those made from thinner material.

A second problem is the provision of an adequate oxygen supply. Divers using self-contained apparatus, particularly when diving deep, may have to carry very large and inconvenient blocks of cylinders in order to stay down long enough to complete a task. In some cases, but not all, a surface supply can be used.

Both these problems are aggravated by a third: decompression. Decompression can not only lengthen the time of a dive, but because of the cold and the limitations of the air supply, may also shorten working time. Several techniques for making decompression less inconvenient have been suggested. Before the war the Royal Navy used submersible decompression chambers (S. D. C.) to enable the diver to complete his decompression in more comfortable surroundings. Even more comfort and efficiency can be gained by the use of a surface decompression chamber used in conjunction with an S.D.C., and such chambers have also been used for maintaining divers at pressure between dives in order to shorten the total time spent in decompression, since the decompression required after a few weeks at depth is no longer than that for 10 hours or so.

Surveys of a wide area such as that of Hiat \& STRASBurg (1960) are most conveniently carried out by numerous short dives which rarely require decompression. Many investigations requiring considerable working time at depth are, however, concerned with small areas of the sea bed. The use of more or less fixed underwater houses has therefore been suggested (e. g. DAvis 1935) and a number have been built. A common feature of these has been their high cost, and although it is difficult to obtain details, the cost per diver-hour must often have been very high - in the region of $\$ 6,000$ for Sealab I, for instance (Skin Diver Magazine, 1964). In addition to the high cost of most underwater houses, few have been very flexible, most being used in 
sheltered areas of warm, clear water. The only experience in cold water is that of the American SEALAb II, and here the cold caused some inconvenience, particularly as the crew spent an average of $2 \mathrm{hrs} /$ day diving (PlatT 1965).

The cost of such houses has, however, been the main factor placing them out of the reach of most marine scientists. An amateur organization recently attempted to show that living underwater for short periods could be done cheaply and simply, and since, apart from a duplicated report published privately, no details have yet been published, the following account is presented.

In the spring of 1965 a small group of amateur divers from the Bournemouth branch of the British Sub-Aqua Club, led by the Branch Scientific Officer, Mr. C. Irwin, put forward plans for a project which involved maintaining two divers at a depth of 10 metres for a week. The Club committee approved the plans, and the house, named GLAUCUS after the legendary Greek fisherman, was built in a local shipyard (Bolson's of Poole). The original reason for the Glaucus project was simply an interest in the problems involved in living underwater, and a desire to show that such projects need not necessarily involve enormous expenditure. As the project progressed, however, it reached a size at which our outlook changed, and more definite aims were formulated. These were essentially threefold. First, to demonstrate that living underwater could be done cheaply and simply while remaining to a large degree independent of the surface; secondly, to show that useful scientific work could be done by such means; and thirdly, to gain practical experience in the design and operation of such a house. The cost of the experiment was met through donations by members of the Club and the Club itself, and from money raised by publicity. The final cost was of the order of $\$ 1,000$.

In the following, the term "dive" denotes an excursion underwater, either from the surface or from an underwater house, while "submersion" is used to mean the period during which an underwater house is submerged.

\section{CONSTRUCTION AND DESIGN OF GLAUCUS}

It is much more convenient to have a house which can be completely sealed, since buoyancy can then be kept constant, making surfacing and submerging easier, and allowing decompression to be carried out in the house itself. SEALAB I, which was not pressurised, flooded partially while being lowered, and the resultant increase in weight made it sink too rapidly, causing some damage. SEALAB II, on the other hand, was pressurised and lowered under pressure. Pressure-tight vessels are not only more expensive to construct, but also need to be pressure-tested, and this, too, is expensive, so it was decided to leave a hatchway at the bottom of Glaucus which would be permanently open to the sea. The size and shape were also influenced a great deal by economic considerations. The basic shape of the house was a flat ended cylinder, this shape giving strength and being easily constructed (Figure 1). It was $2 \mathrm{~m}$ in diameter and $3,5 \mathrm{~m}$ long $(7 \mathrm{ft} \times 12 \mathrm{ft}$ ). It was considered that this would allow enough room for comfort, without making towing difficult or necessitating too much ballast. One corner of the house was separated off by a pair of bulkheads to provide a separate 
lavatory, the air in which could be drained out by means of a pair of turncocks coupled by a polythene hose, after which fresh air could be blown in from the main chamber. This prevented fouling the air in the main chamber, and made it possible to use the lavatory as a ballast tank. Entry into both sections of the house was by a pair of open hatchways in the floor at the lavatory end of the house, the water being kept out by air pressure as in a diving bell. As a safety precaution a porthole was placed in one of

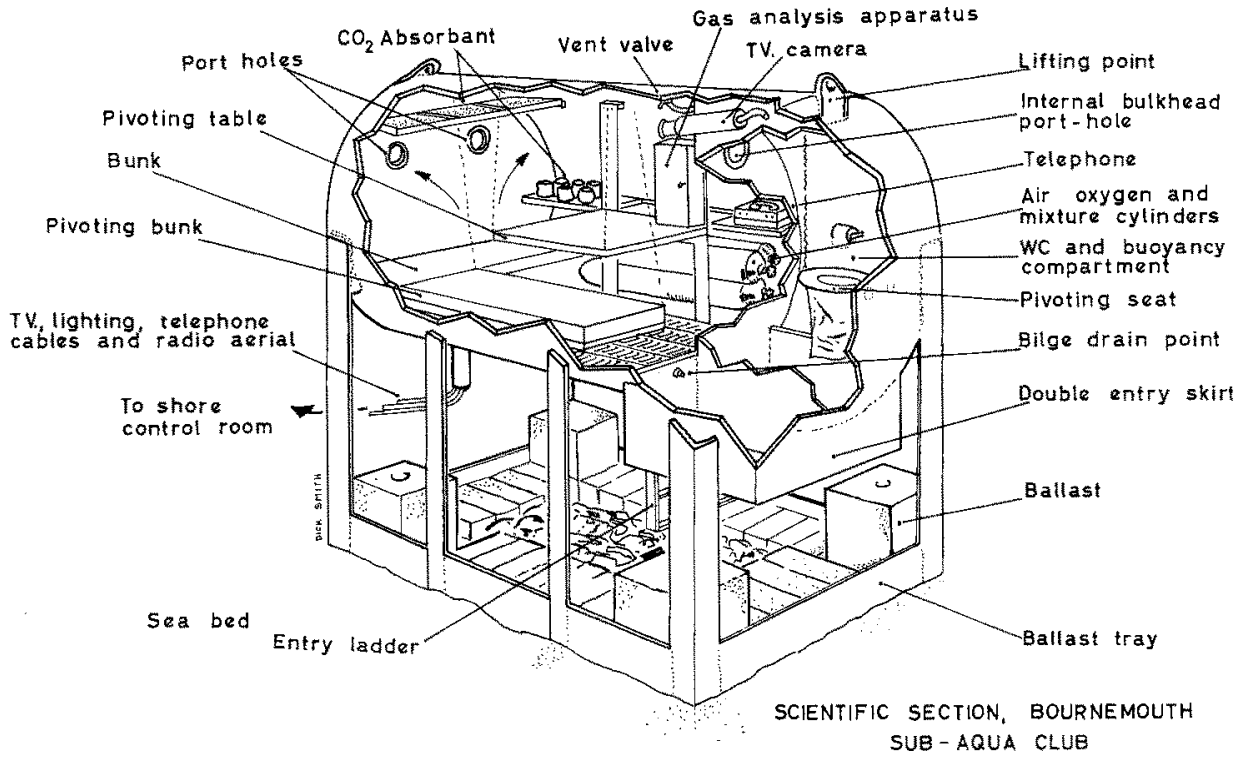

Fig. 1: Diagram of GLAUCUS

the bulkheads separating the lavatory from the main chamber to allow observation of a crew member in the lavatory, and was also useful for checking the amount of air in the lavatory. Two more portholes were placed in the wall at the other end of the house to allow observation of the surroundings.

There were two bunks; one fixed across the end of the cylinder, leaving about $1,4 \times 2 \mathrm{~m}$ of free floor space $(4 \mathrm{ft} 6$ ins $\times 6 \mathrm{ft} 6$ ins), while the other folded against one side wall. Along the opposite wall were shelves and a large table which folded up against them when not in use. Oxygen and air cylinders were stored under the shelves, and the top shelf held a telephone for communication with the surface crew. The telephone and power cables (for lighting) entered the house through a steel pipe welded into the bottom of the house under the end bunk. A closed-circuit television camera, provided by Marconi, was mounted over the entry hatch, and was connected with the surface by a multi-core cable entering the house through the hatchway. Power was supplied by a petrol generator and an emergency battery supply controlled and maintained at the surface. A ballast tray was attached to the house by eight steel legs. The 
ballast, pig iron and sections of railway line weighing roughly $14,000 \mathrm{~kg}$ (13 tons), was adjusted to the correct weight with short sections of railway line and railway sleeper chairs, which weighed about $38 \mathrm{~kg}$ each and were, therefore, light enough to be handled fairly easily by divers. At each end of the house there was a lug for lifting and towing.

\section{CONTROL OF THE ATMOSPHERE}

In the following account, the gas inside Graucus will be termed the atmosphere; the term air refers to a mixture of roughly $21 \%$ oxygen and $79 \%$ nitrogen.

It was intended that Glaucus should remain as independent of the surface as possible; for this reason the atmosphere was controlled by a closed-circuit technique. Though slightly more complicated than the open-circuit method, the closed-circuit technique has several advantages, namely: the house crew can alter oxygen levels at will; ventilation can be increased or decreased as required; the continual noise of exhaust bubbles is largely avoided; the system is more economical and largely independent of the surface. Potential hazards are, however, greater than with open circuit systems, since the atmosphere must be monitored continuously, and toxic substances may build up to a level which would not be reached using an open-circuit system. Our system consisted of four soda-lime trays containing 4-10 mesh British Drug Houses indicator soda-lime ("Carbosorb"). The trays were situated near the roof to take advantage of convection currents of warm, expired air, but no circulation pumps were used. Oxygen was introduced through a pair of bleed valves connected to 3,000 1 $(110 \mathrm{cu} . \mathrm{ft})$ British Oxygen steel cylinders. Air cylinders were also carried for adjusting the volume of the atmosphere, flushing the house out, or adding nitrogen to the atmosphere, the oxygen being consumed by the crew. Carbon dioxide and oxygen levels were monitored by Lioyd's (1958) modification of Haldane's apparatus. Visiting divers were instructed to note any odours in the atmosphere on entering, and activated charcoal was mixed with the soda-lime in one of the trays to absorb impurities other than carbon dioxide.

During a preliminary test on land, hereafter called the dry run, which started at about 10.00 p.m. and lasted for about 18 hours, the carbon dioxide content of the atmosphere rose overnight to about $2,3 \%$. It was successfully lowered to, and maintained at, about $1,2 \%$. About $800 \mathrm{~g} / \mathrm{hr}$ soda-lime was used, soda-lime changes being carried out nearly every $1 \frac{1 / 2}{2}$ hours, except during the night.

One of the crew of two, who was mainly responsible for the soda-lime changes, developed chest pains, and afterwards showed a slight bronchial murmur on medical examination. Moistened cotton gauze smog masks were, therefore, used when changing soda-lime during the submersion, and greater care was taken to avoid raising dust. Although both of the crew experienced slight discomfort on breathing deeply at some periods during the submersion, at no time was this sufficient to cause anxiety.

The carbon dioxide absorption during the experiment was barely adequate. Although carbon dioxide levels dropped slowly when the crew were asleep (Figure 2), exercise, cold, or other divers entering the house rapidly raised the levels, which on 
one occasion reached $2,2 \%$, i. e. about $36 \mathrm{~mm} \mathrm{Hg}$. It was anticipated that fairly high levels might be reached, and a watch was kept for subjective symptoms. One observation of particular interest was made: it was noticed that after a few days breathing appeared to become easier. This agrees with the observations of SCHAEFER et al. (1963a) on submarine personnel subjected to high carbon dioxide pressures. On the other hand, breathing seemed much more difficult on returning to the house after a 15 minute dive

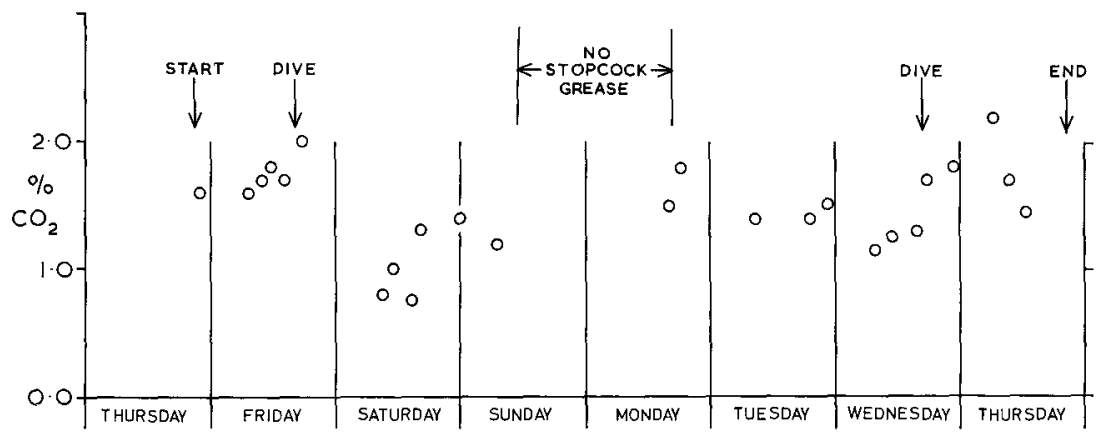

Fig. 2: Carbon dioxide content of the atmosphere

when breathing air, and this dyspnoea appeared to continue for several hours after the dive. As already noted, however, carbon dioxide levels tended to increase after dives, when the diver was cold, and it is therefore impossible to comment further on this without evidence from quantitative ventilation measurements.

Oxygen consumption cannot be discussed without reference to tidal pressure changes. Since the tidal range resulted in a pressure change of about $10 \%$, it is clear that in order to prevent flooding at high tide, large amounts of gas were needed, this gas being subsequently lost at low tide. Gas loss was minimised by allowing the bilges to flood at high tide, but nevertheless, about 2301 ( $80 \mathrm{cu}$. ft) were lost every day. Since the gas leaving the house contained approximately $17 \%$ oxygen, and that entering contained $21 \%$, some of our oxygen requirement was met by these tidal adjustments. One some occasions oxygen was used to blow back the tide, rather than bleeding it in continuously.

On the dry run the great difference between nighttime (inactive) and daytime (active) oxygen consumption was not appreciated, and because of this the oxygen level dropped to $17,9 \%$ on one occasion. During the submersion, however, regulation of oxygen levels proved delightfully simple, and needed very little attention.

About $1,5 \mathrm{~kg}$ of activated charcoal was used during the submersion. Visitors occasionally noted a slight "painty" smell, or other less well-defined odours, but both subjects remained in good health throughout the experiment. We confirmed Cous'tEau's (1963) observation that skin infections can occur when living underwater but consider that in our case this may have been due to the lack of hot water for washing, rather than to the absence of ultra-violet light. 


\section{DIET}

Some thought was given to the provision of a suitable diet for the crew. Because of the cold anticipated, a high-energy diet was required and large amounts of carbohydrate were provided, giving a total energy supply of about $3,000 \mathrm{kcal} / \mathrm{day}$. It was realized that the lack of ultra-violet radiation might give rise to a shortage of vitamin $\mathrm{D}$ which could aggravate any changes in calcium or phosphate metabolism caused by high environmental carbon dioxide pressures (see SchaEfer et al. 1963b), but since the submersion would only last a week, no vitamin $\mathrm{D}$ was added to the diet. It has been estimated (Bell, Davidson \& Scarborough 1963) that the average man eliminates about $500 \mathrm{ml}$ of flatus daily. This would not be too unpleasant, as the sense of smell adapts rapidly, but could be dangerous if toxic concentrations of some compounds built up. To counteract this, in addition to the use of activated charcoal and the provision of a separate lavatory, the diet was low in tryptophan and sulphur compounds to discourage intestinal fermentation. Fried food has been reported (BonD, quoted in Skin Diver Magazine 1964) to liberate acrolein. Although this was not considered important for the depth and duration of the submersion, fried food is not particularly digestible, and so was avoided. The food was cooked on the surface by the ground crew, and delivered to the house in watertight food containers by divers.

\section{SITING AND SINKING}

The house was transported by road from the shipyard at Poole to Plymouth, where the Royal Navy had allowed us to use the Breakwater Fort, $100 \mathrm{~m}$ from the Breakwater and about $3 \mathrm{~km}$ from Plymouth, as a base for the surface crew. This site is sheltered from all winds except west-south-west, and is in telephone contact with the mainland. Glaucus was lowered into the water at Plymouth, and the ballast adjusted to give about $30 \mathrm{~cm}$ freeboard. She was then towed out to the site by a tug (it was later shown that the towing could be done satisfactorily by a $25 \mathrm{ft}$ fishing boat) and sunk by two divers inside, who vented air out through the roof. The rate of descent was controlled by the tug's capstan, the strain never exceeding 6 tons. Additional small ballast was then added to the ballast tray, and, since the two divers working inside had fouled the air, the house was flushed out with clean air from a surface airline. The two house crew entered the house three days later.

\section{DECOMPRESSION}

Dr. Hempleman, of the Royal Naval Physiological Laboratory, had expressed his personal opinion that no decompression would be required for a dive of a week's duration at $9 \mathrm{~m}$, and this was, therefore, the planned depth of the hatchway water level, which would be about $1 \mathrm{~m}$ above the bottom. Unfortunately, the house had been

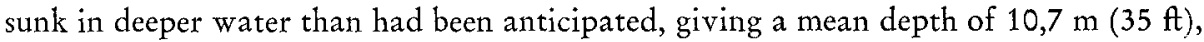
so a somewhat arbitrary decompression schedule was evolved to counter the effects of 
the increased depth. First, the oxygen content of the atmosphere was to be raised to $28 \%$ on the day before surfacing, and to about $40 \%$ on the day of surfacing. After about 8 hours in an atmosphere of 35 to $40 \%$ oxygen, the house was to be raised to the surface, when the hatchway would be $1,7 \mathrm{~m}$ below the surface, allowing a decompression stop at a depth of $1.7 \mathrm{~m}\left(5^{1 / 2} \mathrm{ft}\right)$ for 3 hours. Assuming that this schedule allowed all tissues to reach a nitrogen tension equivalent to a $35 \%$ oxygen, $63.5 \%$ nitrogen atmosphere at $10,7 \mathrm{~m}$, then the tissue nitrogen tension would be 1,31 ats; the ratio between the nitrogen partial pressure and the surface air pressure would thus be $1,31: 1$, and between the nitrogen partial pressure and the absolute pressure at the intended decompression stop 1,31:1,17, or 1,1:1. It is normally considered that the maximum permissible value for this ratio is $1,6: 1$, and it was therefore considered that even if all tissues had not desaturated to a level corresponding to a $63 \%$ nitrogen atmosphere, there would be a wide safety margin. In spite of this, one of the house crew planned to supplement this routine by breathing the $80 \%$ oxygen, $20 \%$ nitrogen mixture used by COUSTEAU (1963) in a similar experiment.

To raise the house, the bilges and lavatory were flooded, and some of the small ballast removed from the ballast tray. Unfortunately, too much was removed, and when the excess water was blown out of the house, Glaucus rose too rapidly, accelerated as the remaining water was forced out by the expanding air, and shot out of the surface before sinking back to her normal floating position, with the hatchway $1.7 \mathrm{~m}$ below the waterline. Since some of the air had been lost at the surface, when the hatch sank to this resting level water was forced in at a pressure of $1,7 \mathrm{~m}$, and the house lost buoyancy, sinking further. The air inside was then further compressed, more buoyancy lost, and the house accelerated rapidly downwards. A second attempt was made, during which air was released into the house from cylinders during surfacing, but although this delayed the subsequent descent slightly, it was unsuccessful. The Royal Navy had agreed to help in an emergency, so the ground crew contacted H. M. S. Drake, the Plymouth Naval Hospital, who provided a motor fishing vessel to pick up the house crew, who were then kept under observation for 24 hours. No symptoms of decompression sickness appeared. The house was later raised by lashing boards across the entrance to hinder the escape of air during surfacing.

\section{THE SUBMERSION: RESULTS AND RECOMMENDATIONS}

The ground crew maintained a 24 hour watch for the duration of the submersion, working six-hour shifts. In addition to manning the telephone and television, they cooked three hot meals a day and brought these down to the house together with any other supplies, and maintained the generator supplying the house with power. They worked under unpleasant conditions, which were further aggravated by a deterioration in the weather.

On the second day of the submersion a west-south-west force 11 gale struck the Plymouth area. It will be recalled that the site was not sheltered from winds in this quarter. The oxygen content of the atmosphere was increased to initiate decompression before a possible emergency exit, and the lavatory and bilges were partially flooded 
to give extra ballast. The house did not move at all during the storm, but the large waves above the house produced pressure changes inside the house which caused some discomfort to the eardrums and made sleeping difficult. One of the boats broke loose, but was recovered the following day. The storm made the water extremely muddy, reducing the visibility to about $30 \mathrm{~cm}$, and strong winds during the rest of the week prevented the dirt from settling appreciably. The visibility on the last day was about $2 \mathrm{~m}$. This made diving from the house more difficult, since guide lines were needed to prevent the divers getting lost, and the biological investigations which had been planned had to be abandoned.

The closed-circuit television gave considerable trouble during the first few days because of sea water in the cable and connecting plugs. A new cable was brought down successfully on the fourth day, and apart from occasional condensation on the front of the lens, the equipment operated satisfactorily for the rest of the week. A radio was fitted up in the house later in the week, purely for the entertainment of the crew, who performed several dives, but did no work because of the unsatisfactory conditions. Since they could not surface during a dive because of the risk of decompression sickness, no lifejackets or snorkels were carried by the house crew. Although the temperature of the house remained between $15^{\circ}$ and $16^{\circ} \mathrm{C}$, the crew felt cold all week, largely because of the difficulty of active exercise in the house: this made diving unpleasant.

Control of the atmosphere presented several problems. The gas analyser was designed for use with less than $25 \%$ of oxygen, and when the oxygen content was raised over the last two days for decompression, the technique of diluting the gas to be analysed with nitrogen took a little while to grasp. Once the correct technique had been acquired, an accuracy of about $\pm 1,5 \%$ total volume was possible. The accuracy obtained with lower oxygen concentrations was about $0,05 \%$. Three other problems were encountered during gas analysis. First, on some occasions pressure changes, both those caused by waves and those caused by the tide, made 'levelling off' very difficult, and with the standard Haldane, which has one more meniscus to adjust, analysis could easily have been made impossible. Secondly, the light was poor, and this made accurate work difficult. Fortunately a large light had been fitted for use with the television camera, and this ameliorated the difficulty to a large extent. Thirdly, there were accidents. Since the author is of a pessimistic turn of mind, spare reagents and mercury were available, and also flowers of sulphur to sprinkle on spilt mercury which was cleaned up as soon as possible, but an adequate supply of stopcock grease was not brought, and this caused some inconvenience.

The main defect in the system was undoubtedly carbon dioxide absorption. Although considerable circulation was supplied by convection currents (as was shown by the fact that soda-lime in a tray placed at floor level changed colour very slowly) this was insufficient. In any future work a circulating pump is recommended. A counterflow system, with the older soda-lime absorbers at the inlet end would conserve soda-lime, which appears to absorb more sluggishly after a time. Other methods have been used to remove carbon dioxide, including the use of a solvent which can be regenerated, and freezing. Both of these are too complicated for a cheap underwater house. It would be useful, however, to have a small refrigeration unit for air drying, 
refrigeration being the most suitable method for the enormous quantities of water involved. The heat exchanger of the refrigeration unit could be placed in the exit stream of the air purification unit to warm the air slightly.

Some form of insulation would be a great advantage, but a heating system, at least for houses in shallow water using a nitrogen atmosphere, is probably an unnecessary luxury.

A semi-automatic atmosphere control system must include reliable and simple safety devices. To guard against pump failure, soda-lime trays or respirators should be available, as should a chemical gas analyser, not only for emergencies, but also for periodic checks of the automatic system. The Lloyd or SCHOLANDER analysers are probably the most suitable. Care must be taken to avoid reagents being blown into the wrong places by the considerable pressure changes which will be experienced; for instance, with the Lloyd, contrary to normal practice, the ground glass cone closing the thermometer space should only be closed during analyses, to avoid sucking back of reagents or mercury. Since power supplies would be needed both for operating the air purifiers and illuminating the gas analyser, an emergency power supply should be available, and a battery-operated light could be fitted to the gas analyser.

The diet also presented difficulties, most of them affecting the surface crew, who had to cook the meals under primitive and unpleasant conditions, and deliver them under equally unpleasant diving conditions. Meals were, therefore, often late, sometimes cold, and occasionally mixed with sea water. In spite of this, the food was adequate and usually hot. No pollution problems were encountered, the air staying sweet for the entire week. In a less experimental project, all food should be cooked, or at least heated, in the house itself. This demands adequate storage space for food and fresh water, and additional power for heating.

Other experiments in living underwater have put some emphasis on psychological changes in the subjects. We are inclined to consider that these reports have, perhaps, been coloured by the presence on the experimental teams of psychologists anxious to observe any changes. Although we experienced some differences of opinion with some members of the surface crew at times, these differences were perhaps less than those occuring between some of the surface crew themselves, and certainly no more than would have been expected under the somewhat arduous conditions. We did, admittedly, get some exhilaration, as from any novel experience. There may be two other reasons for the lack of any mental reaction. Both of us have been diving together for about 5 years, and both were more pre-occupied with the immediate discomforts of cold and damp than with any mental reactions to them. It is possible, however, that in longer submersion, or with harder work or more crew members, mental disturbance might be noted, though we consider this unlikely.

The house design was found wanting on several points. A minor improvement already mentioned would be insulation. In fairly shallow water, expanded polystyrene or similar material might be suitable, but as many of the foaming agents used are highly toxic, extensive tests are indicated. If the house is to be non-pressurized, as a cheap house must be, then provision should be made for tidal adjustments, either by providing air cylinders for blowing back the water - a tiresome procedure in the early hours of the morning - or by incorporating a large 'wettable volume' into the hatch- 
way and surrounding area to allow the tide to move up and down without interfering with the rest of the house. A volume change of about $15 \%$ might be a reasonable figure to aim at. Buoyancy problems experienced with a non-pressurized house are more difficult to solve. A possible compromise might be a house which is normally (i. e. when full of air) a few hundred kilogrammes negative, but which could be made heavier when on the bottom by additional anchoring ballast, and made lighter on the surface, perhaps by flotation bags or a ballast tank. The house would be lowered slowly by a surface vessel, giving the house crew ample time to increase the internal pressure to keep out water, and would be lifted by the same surface vessel after removal of the excess ballast. Decompression is another difficulty with a nonpressurized house, and might be done best by the use of a submersible decompression chamber, and perhaps also a surface chamber.

Power supplies pose another difficult problem. A surface generator, though cheap and simple, could be unsuitable in many cases, and involves either a shore station, as in the present case, or a surface vessel supplying power. A power supply in the house must not contaminate the atmosphere, however, and must not be too bulky. For very short submersions, lead/acid accumulators might do, but they would have to be in a compartment isolated from the living quarters to avoid contamination of the atmosphere, and, for longer periods than a fortnight, would probably be too bulky. Fuel cells or other types of accumulators might be an alternative, but could be too expensive. As far as the author is aware, no underwater house used at the present time has a built-in power supply. Although the interior of Glaucus appeared relatively cramped, it was quite adequate for two people, and three could work in it without undue restriction. Nevertheless, a separate 'wet chamber', preferably with a hot shower for divers, would make diving more comfortable and efficient. The floor of such a wet chamber could provide some of the 'wettable volume' needed for accommodating tidal pressure changes.

It is difficult to compare Glaucus with any other underwater house, with the possible exception of Cousteau's early 'Drogene', but a few points are worth noting. First, we showed that living underwater could be cheaper and more simple than most other experience has indicated. However, expensive development is needed before a cheap house of practical value can be produced. Secondly, we showed that even in shallow water, underwater houses are negligibly affected by heavy seas, and so could perhaps be used in more exposed sites than has been the practice in the past. Thirdly, the closed-circuit atmosphere control system, believed to be the first used in an underwater house, worked adequately, indicating that atmosphere control, even using a closed-circuit system presents no problems in shallow water.

It is hoped that the suggested improvements (insulation, a 'wet chamber', etc.) and results acquired during the Glaucus project will be tested and elaborated by further work. We feel that the underwater house, particularly if it can be made selfcontained without becoming unduly complex or expensive, will become an important tool for divers of many disciplines. 


\section{SUMMARY}

1. Two divers have been maintained satisfactorily at a depth of $10,7 \mathrm{~m}$ for a week by means of a cheap and simple underwater house.

2. The house was unaffected by heavy seas, indicating that underwater houses can be used in exposed sites.

3. A simple closed-circuit system of air purification was used for the first time in an underwater house.

\section{LITERATURE CITED}

Barada, W., 1964. Sealab 2. Skin Diver Mag. 1964 (Aug.).

Bell, G., Davidson, J. \& Scarborough, H., 1963. A textbook of physiology and biochemistry. 5th ed. Williams \& Wilkins, Baltimore, Md ([1961] London 1963), $1117 \mathrm{pp.}$

Cousteau, J.-Y., 1963. The era of "Homo aquaticus". In: The undersea challenge. A report of the proceedings of the 2 nd World Congress of underwater activities, London 1962. Ed. by B. Eaton. British Sub-aqua Club, Kingston-on-Thames, Surrey, 182 pp.

Davis, R. H., 1935. Deep living and submarine operations. A manual for deep sea divers and compressed air workers. St Catherine pr., London, $509 \mathrm{pp}$.

Drach, P., 1952. Lacunes dans la connaissance de peuplement des mers et utilisation des scaphandres autonomes. Revue scient., Paris 90, 58-72.

Dugnn, J., 1960. Man explores the sea. Penguin Books, Harmondsworth, Middlesex, $416 \mathrm{pp}$.

Gosline, W. A., 1965. Vertical zonation of inshore fishes in the upper water layers of the Hawaiian islands. Ecology 48, 823-831.

Hiat, R. W. \& Strasburg, D. W., 1960. Ecological relationships of the fish fauna on coral reefs of the Marshall Islands. Ecol. Monogr. 30, 65-127.

Kitching, J. A., 1941. Studies in sublittoral ecology. III. Laminaria forest on the west coast of Scotland: A study in zonation in relation to wave action and illumination. Biol. Bull. mar. biol. Lab., Woods Hole 80, 324-337.

- Macan, T. T. \& Gilson, H. C., 1934. Studies in sublittoral ecology. 1. A submarine gully in Wembury Bay, S. Devon. J. mar. biol. Ass. U. K. 19, 677-705.

Laborel, J. \& Vacelet, J., 1958. Etude des peuplements d'une grotte sous-marine du Golfe de Marseille. Bull. Inst. oceanogr. Monaco 55 (1120), 1-20.

- - 1961. Repartition bionomique de Corallium rubrum Lмк. dans les grottes et falaises sousmarines. Rapp. P.-v. Réun. Commn int. Explor. scient. Mer Méditerr. 16, 465-470.

Lloyd, B. B., 1958. Development of Haldane's gas analysis apparatus. J. Physiol. Lond. 143, $58-68$.

Platt, R. G., 1965. Pioneering "Inner space" - Sealab II. Geo-mar. Technol. 1 (8), 7-13.

QATREFAGES DE BRÉAU, J. L. A., 1857. The rambles of a naturalist on the coasts of France, Spain and Sicily (Souvenirs d'un naturaliste). Transl. from the French by E. C. Otte. H. Bohn, London, Vol. 1.2.

Schaefer, K. E., Hastings, B. J., Carey, C. R. \& Nichols, Jr, G., 1963a. Respiratory acclimatization to carbon dioxide. J.appl. Physiol. 18, 1071-1078.

- Nichols, G. \& Carey, C. R., 1963b. Calcium and phosphorus metabolism in man during acclimatization to carbon dioxide. J. appl. Physiol. 18, 1079-1084.

\section{Discussion following the paper by HEATH}

BARNES: Can you give any estimate of the increased expense necessary to make the apparatus adequate for "ordinary" people? 
HEATH: This is a very difficult question to answer. Various commercial interests are producing systems for individual use. The cost of these is of the order of $£ 100,000$. However, I think that by using simpler methods, for instance, instead of employing automatic atmosphere control systems, using the diver to do the work of gas analysis, much cheaper systems could be produced.

Hartnoll: Do you consider that at depths below $9 \mathrm{~m}$ it will be safe to use such equipment if the chamber is not pressurable, or if a submersible decompression chamber is not available?

Heath: This depends on the depth. For submersions to $11 \mathrm{~m}$ adequate oxygen-rebreathing methods are available. However, for deeper work, and I feel that you must go to at least $18 \mathrm{~m}$ to make an underwater house worthwhile, a submersible decompression chamber, at least, will be required, and preferably also a surface chamber. 